Journal of Business Management and
Economic Research

\title{
The Efficiency of Development Investment in Agricultural Production Applying Good Agricultural Practices (Gap) Standard of Household - Case Study of Grapes and Apple in Ninh Thuan Province, Vietnam
}

\author{
Dao Quyet Thang PhD. \\ Quy Nhon University, Vietnam
}

Doan Viet Dung PhD.

National Economics University, Vietnam

\begin{abstract}
Development investement of agricultural production with Good Agricultural Practices (GAP) standards is an objective trend of sustainable agriculture. The study used methods of the Data Envelopment Analysis (DEA), compare means and Difference in Differences (DID) to Assessing the effectiveness of development investement in agricultural production applying GAP standard of household with grape and apple production in Ninh Thuan province, Vietnam. The results indicate that participation in GAP does not really make a difference in technical efficiency (TE) compared to the rest of the group due to the large dispersion, but it led to an increase in the Total Factor Productivity Change (TFPCH) higher than the other groups. Therefore, it is necessary to find solutions to promote investment in agricultural production following GAP standards.
\end{abstract}

Keywords: GAP, Investment efficiency, Agricuture, Farmer household, Ninh Thuan, Vietnam

\section{Introduction}

Agricultural production with GAP will create a solid foundation for sustainable development agriculture, not only in Viet Nam but also many countries of the world. The agricultural products meet the GAP quality standards to penetrate global agricutural market and bring more benefits to farmers. Agricultural production with GAP standards ensures safety for comsumers, producers and also protects rural environment. For that reason, development investment of agricultural production directs to the purpose of developing products to meet the GAP quality standards.

Ninh Thuan is one of the farming provinces in Vietnam in grape and apple products. Farmer households in Ninh Thuan started to participate GAP standards in production of these products since 2013. In addition to, achievements such as expanding cultivation area and increasing prestige and brand of these products, there are still difficulties and limitations in increase of production scale and market development. 
The study aims to investigate the efficiency of development investement in agricultural production applying gap standard of household, by using three main methods of DEA, compare means and DID, in order to provide farmers and state managers with objective view of real benefits of GAP adoption.

\section{Literature Review}

According to Reardon and Farina (2001) stated a food producer can have advantage over its competitors through applying techniques to enhance food safety. Sharing this point of view, Holleran et al. (1999), incentives based on that production units invest in measures to control food safety have originated from both in-side producers and out-side customers and governmental regulations. Studies of Wannamolee (2008), Mushobozi (2010), Jiao et al (2010), Henson và Northen (1998) show that partners with-in agricultural supply chain including producers, distributors as well as consumers play very important roles in encouraging application of food safety standards in which GAP is generally basic one.

Hobbs (2003) argued that GAP benefits can divide in two aspects. The first one is to reduce farmers' production costs by effective use of labors, reasonable selection of inputs and application of good methods. In a case-study of Kenya, GAP help reduce significantly costs of vegetable production. This production method contributes to improve production effectiveness in terms of economic, social and environmental aspects. GAP help farmers control production costs by applying appropriate farming techniques. The second one is to contribute to increase selling prices of agricultural products. GAP is to help enhance product quality, thus, GAP's products can penetrate markets with higher standards. However, when supply of GAP products increased, risk of reduced prices is unavoidable.

In order to ensure strictly standards of GAP, it is necessary to have significantly invest in technical training on production, processing, selections of inputs (seed/seedlings, fertilizers, etc.) as well as in getting regularly certification of quality audits (Okello and Swinton, 2007; Graffham et al., 2007). These impact on production efficiency in the case that outputs achieved is not proportionally. As the result, this make difficulty for small farmers and facilitate sized enterprises in agricultural production with GAP standards, as examples in Kenya (Mungai, 2004; Graffham, 2006; Asfaw, 2007; Graffham et al., 2007) and Uganda (Kleih et al., 2007). However, higher effectiveness of investment in agriculture with GAP have stimulated small farmers to adopt GAP. To be able to protect themselves from competition with enterprises, many small farmers have co-operated each other to set up an organization of agricultural production with GAP standards and have succeeded, as in Zimbabwe (Henson et al., 2005) and in Madagascar (Minton et al., 2007), or made linkages between small farmers and enterprises as in several projects of EurepGAP in Zambia (Graffham and MacGregor, 2007).

Using the index of Technical Efficiency (TE) and Total Factor Productivity Change (TFPCH) as index of Malmquist in Data Envelopment Analysis (DEA) to measure efficiency of development investment have been carried out by many authors, especially in agricultural investment, such as Lin, 1992; Fan and Pardey, 1997; Mao and Koo, 1997; Jin et al., 2002; Fan \& Zhan, 2002; Chen el al., 2008. These studies used different input and output indexes to measure TFPCH index, for example, Lin (1992) used 4 normal inputs and 6 supplement variables, Fan and Pardey (1997) used 5 normal input variables and 2 supplement variables, main input factors used by these authors were based on Cobb-Douglas production function.

Fan et al. (2004) also showed that increasing of R \& D in agriculture, rural education and infrastructure by supports from Government would contribute to increase of Total Factor Productivity of agriculture. Fan và Pardey (1997) have stated that change in production techniques lead to significant change in the Total Factor Productivity. Thus, it is said that 
farmers' adoption in development of agriculture with GAP would make changes in production techniques, infrastructure, knowledge of production, etc. These might significantly impact on TE and TFPCH.

\section{Data and methodology}

\subsection{Research site}

Ninh Thuan located in the south central coast in the central area of Vietnam. There are some favourable conditions for development of agricuture following GAP standards especially grape and apple plantation, such as appropiate climate for cultivating grape and apple; most farmers with long-time experiences of these fruit plantations. At the year of 2016 Ninh Thuan ranked the third province in number of farmer groups that have invested in developing grape and apple productions following VietGAP standards, with grape area of 280 ha and apple area of 47.2 ha. However, there are several difficuties in sustainable agriculture development here namely poor livelihoods, low education levels and limited capital sources of farmers, having located far from economic centers and big cities. Solving these barries would make theoretical and practical constributions to GAP agriculture in developing countries generally and in Vietnam particularly.

\subsection{Data collection}

Data in this research was gathered through surveying 200 farmer households in Ninh Thuan province wih using structured questionaires.

Primary data was collected using ramdom and leveling methods in Ninh Thuan with sample sise of 200 farmer households in which 100 households cultivating with VietGAP standards who represented for 88 GAP linkage groups of farmers and 100 farmer households with-out VietGAP agricultural prodution. Leveling was based on terms of locations and linkage groups. There are total 88 GAP linkage groups of farmers in Ninh Thuan province (Vietgap.com.vn) with total 1.272 farmer househols, in which 27 groups at Phan Rang - Thap Cham city, 26 groups in Ninh Hai district, 20 groups in Ninh Phuoc district, 10 groups in Ninh Son district and 5 groups in Thuan Nam district. The research based on sizes of linkage groups of farmers to select farmer groups for survey, after that, seleted randomly households in the surveyed groups of farmers.

\subsection{Data analysis methods}

According to DEA, the ML (Malmquist) formula to calculate TFPCH can be decomposed into two components: technical change and efficiency change (Grosskopf et al., 1994). The efficiency change can further be decomposed into pure efficiency change and scale efficiency change. The "technical change" component measures the shift in the frontier over time and can be interpreted as providing evidence of innovation for the province considered. The "pure efficiency change" component measures the extent to which observed production is moving toward (or away from) the frontier, which is constructed by the best practice provinces based on the variable returns to scales (VRS) technology. The pure efficiency change component, therefore, captures the performance relative to the best practice in the sample and can be interpreted as the catching-up effect. The "scale efficiency" in a given period captures the deviations between the VRS technology and the CRS technology at observed input levels. So the TFPCH formula can be written as follows: 


$$
\begin{gathered}
\text { TFPCH }=(\text { TECH }) \times(\text { EFFI })=(\text { TECH }) \times(\text { PUREFF }) \times(S C A L) \\
\text { where TECH }=\left[\frac{d_{c}^{t}\left(x^{t+1}, y^{t+1}\right)}{d_{c}^{t+1}\left(x^{t+1}, y^{t+1}\right)} \times \frac{d_{c}^{t}\left(x^{t}, y^{t}\right)}{d_{c}^{t+1}\left(x^{t}, y^{t}\right)}\right]^{1 / 2}, \\
\text { EFFI }=\frac{d_{c}^{t+1}\left(x^{t+1}, y^{t+1}\right)}{d_{c}^{t}\left(x^{t}, y^{t}\right)}, \\
\text { PUREFF }=\frac{d_{v}^{t+1}\left(x^{t+1}, y^{t+1}\right)}{d_{v}^{t}\left(x^{t}, y^{t}\right)}, \text { and } \\
S C A L=\frac{d_{c}^{t+1}\left(x^{t+1}, y^{t+1}\right)}{d_{v}^{t+1}\left(x^{t+1}, y^{t+1}\right)} / \frac{d_{c}^{t}\left(x^{t}, y^{t}\right) .}{d_{v}^{t}\left(x^{t}, y^{t}\right)}
\end{gathered}
$$

This research uses the method of Data Envelopment Analysis (DEA) for criteria of maximizing Variable Returns to Scales (VRS) to measure Technical Efficiency (TE) and Total Factor Productivity Change (TFPCH). According to Cobb-Douglass production function, outputs depend on four factors of capital, labour, natural resources and technology. The research uses four input factors namely annual production costs/ha/year, initial investment costs/ha, number of labour and cultivating area, and three outputs namely average yield/ha/year, average profit/ha/year và average revenue/ha/year to measure total efficiency.

The research uses methods of compare means and Difference in Differences (DID) to Assessing the effectiveness of development investement in agricultural production applying GAP

\begin{tabular}{|c|c|c|c|c|c|}
\hline & Target & $\begin{array}{c}\text { Non-GAP } \\
\text { production } \\
(\text { million } \\
V N D / h a) \\
\end{array}$ & $\begin{array}{l}\text { Structure } \\
(\%)\end{array}$ & $\begin{array}{l}\text { GAP production } \\
\text { (million } V N D / h a)\end{array}$ & Structure $(\%)$ \\
\hline A & Initial investment & & & & \\
\hline 1 & Certificate registration GAP & & & $\begin{array}{l}\text { Supported by } \\
\text { the Government }\end{array}$ & \\
\hline 2 & Initial technical training & & & $\begin{array}{l}\text { Supported by } \\
\text { the Government }\end{array}$ & \\
\hline 3 & $\begin{array}{l}\text { Initial infrastructure } \\
\text { investment }\end{array}$ & 145.53 & $14.64 \%$ & 330.41 & $26.99 \%$ \\
\hline B & $\begin{array}{l}\text { Basic construction } \\
\text { investment }\end{array}$ & 484.42 & $48.73 \%$ & 468.66 & $38.28 \%$ \\
\hline C & $\begin{array}{l}\text { Average investment of } 3 \\
\text { crops/year }\end{array}$ & 364.19 & $36.63 \%$ & 425.08 & $34.72 \%$ \\
\hline
\end{tabular}
standard of farmer households' investment in agricultural development,

\section{Results and discussion}

\subsection{Current status of investment in agricultural production development of farm households}

Table 4.1. The average investment of farm households with GAP and non-GAP production

Source: Results collected from the survey of 200 households in Ninh Thuan 
Total investment to infrastructure preparation to harvest was 799.1 million VND / ha, more than non-GAP 169.1 million VND / ha. The initial infrastructure investment was 330.41 million VND / ha, the investment to agricultural materials and labor was 468.66 million VND / ha. The investment period lasts about 9 months to 1 year depending on climatic conditions, soil,... and growth ability of trees. Each year, the farmers invest 3 crops, the investment with GAP is about 425.08 million VND / ha, while investment without non-GAP is just 364.19 million VND / ha. It can be seen that the structure of investment is mainly focused on basic construction investment. Thus, during this period, farmers should focus on searching financial resources so as not to affect the investment progress.

Table 4.2: Difference -in -Differences regression results for investment performance with GAP of farm households in Ninh Thuan Province in 2016

Unit of account: million $V N D / h a$

\begin{tabular}{|c|c|c|c|c|c|}
\hline & \multirow[b]{2}{*}{ Target } & \multicolumn{2}{|c|}{ Difference } & \multicolumn{2}{|c|}{ Diff-in-diff } \\
\hline & & $\mathrm{Xi}(\mathrm{s})-\mathrm{Xi}(\mathrm{t})$ & Sig. & $\begin{array}{l}\Delta \mathrm{Xi}(\mathrm{GAP}=1)- \\
\Delta \mathrm{Xi}(\mathrm{GAP}=0)\end{array}$ & Sig. \\
\hline \multirow{2}{*}{1} & Investment capital (GAP) & 542.56 & 0,000 & \multirow{2}{*}{160.71} & \multirow{2}{*}{0,000} \\
\hline & Investment capital (non-GAP) & 381.85 & 0,000 & & \\
\hline \multirow{2}{*}{2} & Asset investment cost (GAP) & 250.68 & 0,000 & \multirow{2}{*}{180.03} & \multirow{2}{*}{0,000} \\
\hline & Asset investment cost (non-GAP) & 70.65 & 0,000 & & \\
\hline \multirow{2}{*}{3} & Average production cost $(\mathrm{GAP}=1)$ & 207.71 & 0,000 & \multirow{2}{*}{47.67} & \multirow{2}{*}{0,000} \\
\hline & Average production cost (non-GAP) & 160.04 & 0,000 & & \\
\hline \multirow{2}{*}{4} & Average profit (GAP) & 249.95 & 0,000 & \multirow{2}{*}{135.46} & \multirow{2}{*}{0,000} \\
\hline & Average profit (non-GAP) & 114.49 & 0,000 & & \\
\hline
\end{tabular}

Source: Calculated results from 200 surveyed households in Ninh Thuan

The results show that compared with non-GAP producers, GAP participations have increased the total investment capital 160.71 million VND/ha, the fixed asset investment cost was 180 million VND/ha, the annual average production cost was 47.67 million VND/ha/year with a significance level of $99 \%$. Participating GAP has also contributed to increasing profit by 135.46 million/ha/year with significance level of $99 \%$. Thus, it can be concluded that participation in GAP production will increase the initial investment and the annual investment but the profit is higher in comparison with non-GAP productions. So in case farmers have favorable production conditions and can mobilize additional capital investment as the amount of capital investment, they should be investing in the production according to the GAP because it will generate higher profit than non-GAP production.

\subsection{Investment efficiency of agricultural production development of farm households}

Analysis DEA of two groups of GAP and GAP-based on 1 data envelopment for both producer groups, for the maximization of output in case of scale change (VRS), the results are as follows: 
Journal of Business Management and Economic Research, vol.3, issue.1, pp.8-16

Table 4.3: TE technical efficiency table under DEA model results in 2016

\begin{tabular}{|c|c|c|c|c|c|c|c|c|}
\hline & \multicolumn{3}{|c|}{ Non-GAP production } & \multicolumn{3}{c|}{ GAP production } \\
\cline { 2 - 9 } & Mean & Max & Min. & $\begin{array}{c}\text { Std. } \\
\text { Dev. }\end{array}$ & Mean & Max & Min. & $\begin{array}{c}\text { Std. } \\
\text { Dev. }\end{array}$ \\
\hline $\mathrm{TE}$ & 0.8704 & 1 & 0.7205 & 0.0647 & 0.861 & 1 & 0.6775 & 0.0885 \\
\hline $\mathrm{TFPCH}$ & 0.8576 & 1.2037 & 0.6472 & 0.119 & 0.977 & 1.4493 & 0.7449 & 0.1564 \\
\hline
\end{tabular}

Source: Results collected from the survey of 200 households in Ninh Thuan

Table 4.4: Table comparing the difference between the two groups of households about the change in aggregate productivity by index Malmquist index 2016

\begin{tabular}{|c|c|c|c|}
\hline \multirow{2}{*}{ number } & \multirow{2}{*}{ Target } & \multicolumn{2}{|c|}{ Difference } \\
\cline { 3 - 4 } & & $\mathrm{Xi}(\mathrm{GAP}=1)-\mathrm{Xi}(\mathrm{GAP}=0)$ & Sig. \\
\hline 1 & TE & -0.0094 & 0.395 \\
\hline 2 & TFPCH & 0.1195 & 0.000 \\
\hline
\end{tabular}

Source: Results collected from the survey of 200 households in Ninh Thuan

Through analysis results in table 4.3, the average technical efficiency of both groups are quite high, in which group of non-GAP production is higher than group applying GAP. This suggests that, due to the burden of inputs sizable group GAP while not increased commensurate output technical efficiency lead to inferior technical performance than the remaining group. In addition, the standard deviation of the group according to GAP higher than non-GAP group, this shows the degree of dispersion of effective value of investment group under the GAP is quite high. However, according to results of testing the differences in technical efficiency between the two groups of production, there is lack of empirical evidence to conclude that nonGAP production is technically more effective than the remaining group with the $90 \%$ significance level (Table 4.4).

Estimated result in Table 4.3 also shows the decline in aggregate productivity growth (TFPCH) of the following period in comparison with the previous period in both groups. In particular, the group produced under GAP reduced $2.29 \%$ while the non-GAP decreased to $14.24 \%$. This due to multiple reason, namely due to increased levels of inputs such as capital investment, labor ... of a later stage compared with the previous period, while the increase of the output again lower. According to the results of the comparison in Table 4.4 shows the investment group under the GAP created increased aggregate productivity levels than before joining GAP higher than the remaining group with a significance level of $99 \%$ is $11.95 \%$. This suggests, the GAP has a positive impact to improve the productivity of farm households investing in the production of grapes and apples in Ninh Thuan, however the group produced under GAP must also get a higher level of risk because the dispersion aggregate productivity growth is larger (the production team under the GAP has a standard deviation is highter than the rest team: $0.0374)$.

\subsection{The problems and reasons}

- Besides the achievement on the development of agricultural production according to the GAP of the farmers, there still many problems to be solved: 
Firstly, the proportion of farm households joined the investment with GAP is limited. In Ninh Thuan, in total 6360 households producing of grapes and apples, there were only 1272 GAP investment producers.

Second, in the households according to the investment GAP, the scale and investment area but have increased but not significantly. It demonstrates in Ninh Thuan agriculture investment by GAP has not yet truly attractive to farmers.

- Although Ninh Thuan is a place where development of grape and apple production is possible, further, more developed agricultural production under GAP is an inevitable trend in Vietnam as well as in the world, but why farmers have not really interested in investment to agricultural production according to GAP? That is due to several causes:

Firstly, the production in Ninh Thuan is spontaneous, although the local planning has developed but not paid attention to the organization of the implementation of the plan, which affects the attracting farmers to invest in development under the GAP.

Second, the understanding of the farm households about the GAP are limited, so they do not understand the benefits of GAP production and therefore have not paid much attention to the development of GAP production.

Thirdly, the consumer market is also spontaneous and fragmented, so it has not built the confidence of customers, so the farmers have not seen the economic effect so they do not stimulate investment according to GAP.

Fourthly, there is no association between the government closely, farmers, businesses and scientists. So not to promote the efficiency of investment in production according to GAP should farmers not really confident in investing in GAP.

\section{Conclusions}

Investment in agricultural development following GAP standards is an indispensable way to develop sustainable agriculture, contributing to the safety of producers, meeting the increasing demands of consumers and protecting the environment. The farmer's agricultural production with GAP is still limited. The study based on data of 200 farmer households cultivating grape and apple stated that adoption of GAP has positively impacted on the efficiency of agricultural investement, and this result supports to points of view of Hobbs (2003), Fan and Pardey (1997) and Fan et al. (2004). However, increase in TFP (compared with TFP before adoption of GAP) is still under potential. The reason is that application of GAP are not effective as expected. Thus, it is necessary to find out appropriate solutions to speed up agricultural production with GAP in terms of both quantity and quality.

In our point of view, it is necessary to implement following solutions: (1) Planning and organizing areas of safety agricultural production that are appropriate to each local province. This will create conditions and orientations for famer household to invest in agricultural production with different GAP standards driven by market demands. (2) Enhancing knowledge and skills of GAP production for famer households. This help them understand efficiency of adoption of GAP and know how to invest in agricultural production with GAP standards. (3) Developing markets for agricultural products certified GAP standards. This is the crucial condition to ensure sustainability of adoption of investing in GAP of famer households. (4) Implementing linkages between 4 shareholders of farmers, firm state managers and scientists. In development of GAP agriculture, small famers could not do themselves separately. Positive participation of related shareholders is very important for development of GAP agriculture. 
Journal of Business Management and Economic Research, vol.3, issue.1, pp.8-16

\section{References}

Asfaw, S. (2007), "Does EurepGAP standard marginalize poor farmers? Evidence from Kenya", Entwicklung and Landlicher Raum, Vol. 1

Fan, S., Pardey, P.G., (1997), "Research, Productivity, and Output Growth in Chinese Agriculture", Journal of Development Economics, 53, 115-137.

Fan, S., Zhang L., Zhang, X., (2004), "Reforms, Investment, and Poverty in Rural China", Economic Development and Cultural Change, 52, 395-421.

Fan, S., Zhang, X., (2002), "Production and Productivity Growth in Chinese Agriculture: New National and Regional Measures", Economic Development and Cultural Change, 50, 819-838.

Graffham, A. (2006), European standards affect African growers. Pesticide news 71, Developing country initiative

Graffham, A., \& MacGregor, J. (2007). Impact of EurepGAP on small-scale vegetable growers in Zambia. Fresh insights.

Graffham, A., Karehu, E., \& MacGregor, J. (2007), Impact of EurepGAP on small-scale vegetable growers in Kenya, Fresh insights.

Grosskopf, S., Färe, R., Norris, M., Zhang, Z., (1994), "Productivity Growth, Technical Progress, and Efficiency Change in Industrialized Countries", American Economic Review, 84, 66-83.

Henson, S. J., Masakure, O., \& Boselie, D. (2005),“Private food safety and quality standards for fresh produce exporters: The case of hortico agrisystems, Zimbabwe", Food Policy, vol. 30, pp. 371-384.

Henson, S., \& Northen, J. (1998), “Economic determinants of food safety controls in supply of retailer own-branded products in United Kingdom", Agribusiness, vol. 14, issue 2, pp. 113126.

Hobbs, J.E. (2003), Incentives for the Adoption of Good Agricultural Practices (GAPs), Background paper for the FAO consultation on Good Agricultural Practices, Rome

Holleran, E., Bredahl, M. E., \& Zaibet, L. (1999), “Private incentives for adopting food safety and quality assurance", Food policy, vol. 24, issue 6, pp. 669-683.

Janvry, A.D. and Sadoulet, E. (2000), “Making Investment in the Rural Poor into Good Business: New Perspectives for Rural Development in Latin America", Conference on Development of the Rural Economy and Poverty Reduction in LAC, at the Annual Meeting of the Inter-American Development Bank, New Orleans

Jiao, W., Fu, Z., Mu, W., Mclaughlin, N. và Xu, M. (2010), “Influence of supply chain model on quality and safety control of table grape and performance of small-scale vinegrowers in China", British Food Journal, Vol. 114 Issue: 7, pp. 978-996

Jin, S., Huang, J., Hu, R., Rozelle, S., (2002), „The Creation and Spread of Technology and Total Factor Productivity in China's Agriculture", American Journal of Agricultural Economics, 84, 916-930.

Kleih, U., Ssango, F., Kyazze, F., Graffham, A., \& MacGregor, J. (2007), Impact of EurepGAP on small- scale fruit and vegetable growers in Uganda, Fresh insights 10

Lin, J.Y., (1992), "Rural Reforms and Agricultural Growth in China", American Economic Review, $82,34-51$. 
Mao, W., Koo, W.W., (1997), "Productivity Growth, Technological Progress, and Efficiency Change in Chinese Agriculture after Rural Economic Reforms: A DEA Approach", China Economic Review ,8, 157-174.

Minton, B., Randrianarison, L., \& Swinnen, J. F. M. (2007), “Global supply chains, poverty and the environment: Evidence from Madagascar", In J. F. M. Swinnen (Ed.), Global supply chains, standards, and the poor: How the globalization of food systems and standards affects rural development and poverty, Wallingford, UK: CABI, pp. 147-157

Mungai, N. (2004). EU rules could destroy horticulture: The protocol on good agricultural practices will have a profound impact on both large and small-scale farmers, alhough the biggest impact will be on the latter. Daily nation 7, Nairobi.

Mushobozi, W.L. (2010), Good Agricultural Practices (GAP) on horticultural production for extension staff in Tanzania, Food and Agriculture organization of the United Nations, Rome.

Okello, J. J., \& Swinton, S. M. (2007), “Compliance with international food safety standards in Kenya's green bean industry: Comparison of a small- and a large-scale farm producing for export", Review of Agricultural Economics, vol. 29, issue 2, pp. 269-285.

Po-Chi, Chen, Y. U. Ming-Miin, Ching-Cheng Chang, and H. S. U. Shih-Hsun (2008), "Total factor productivity growth in China's agricultural sector", China Economic Review, 19, no. 4 580-593.

Reardon, T. and Farina, E. (2001), "The rise of private food quality and safety standards: illustrations from Brazil", International Food and Agribusiness Management review, vol. 4, pp. 413-421.

Wannamolee, W. (2008), “Development of Good Agricultural Practices (GAP) for Fruit and Vegetables in Thailand", Good Agricultural Practices (GAP) and Benchmarking: Global GAP for Fruit and Vegetable, Sheraton Subang Hotel and Tower, Kuala Lumpur, Malaysia, 14-23 July 2008, Science and Education Publishing.

http://vietgap.com/ 